Research Article

\title{
Depression, anxiety, and stress levels in Denpasar community during the pandemic of Corona Virus Disease 2019 (COVID-19)
}

I Gusti Ngurah Bagus Rai Mulya Hartawan¹, I Gede Gita Sastrawan, Rovie Hikari Parastan', Luh Seri Ani²

1) Faculty of Medicine, Udayana University, Bali

2) Public Health Department, Faculty of Medicine, Udayana University, Bali

A R T I C L E I N F O

$\begin{array}{ll}\text { Submitted } & \text { : June } 2020 \\ \text { Accepted } & \text { : October } 2020 \\ \text { Published } & \text { : January } 2021\end{array}$

\section{Keywords:}

depression, anxiety, stress, Denpasar community, COVID-19

\section{*Correspondence:}

gitasastrawan@student.unud.ac.id

\section{ABSTRACT}

The Government of Indonesia has started to implement a Large-Scale Social Limitation (PSBB) in cities and provinces in Indonesia to prevent the increase of COVID-19 transmission. Denpasar city is one of the cities that implemented a similar system. This study aimed to provide an overview of depression, anxiety, and stress in the Denpasar community during the COVID-19 pandemic. This study was a descriptive observational study with a crosssectional design. The data collection used Google forms that were distributed online. There were 160 respondents participated in this study, dominated by women $(56.9 \%)$, domiciled in South Denpasar (35.0\%), living with family or relatives $(85.6 \%)$, aged $18-25$ years old $(63.7 \%)$, had a diploma or bachelor degree as their education background $(55.0 \%)$, unmarried $(66.3 \%)$, students $(38.8 \%)$, and no income $(44.4 \%)$. The results showed that respondents had 1-2 offspring (53.7\%), did not experience layoffs $(83.9 \%)$, and experienced a decrease in income (67.0\%). Dominant respondents experienced psychosocial disorders in the form of depression (51.2\%) with a moderate degree $(31.7 \%)$ and anxiety (53.1\%) with a mild degree $(40.0 \%)$. Most respondents did not experience stress (53.1\%). In conclusion, the characteristics of respondents' psychosocial disorders were moderate depression, mild anxiety, and did not stress. 


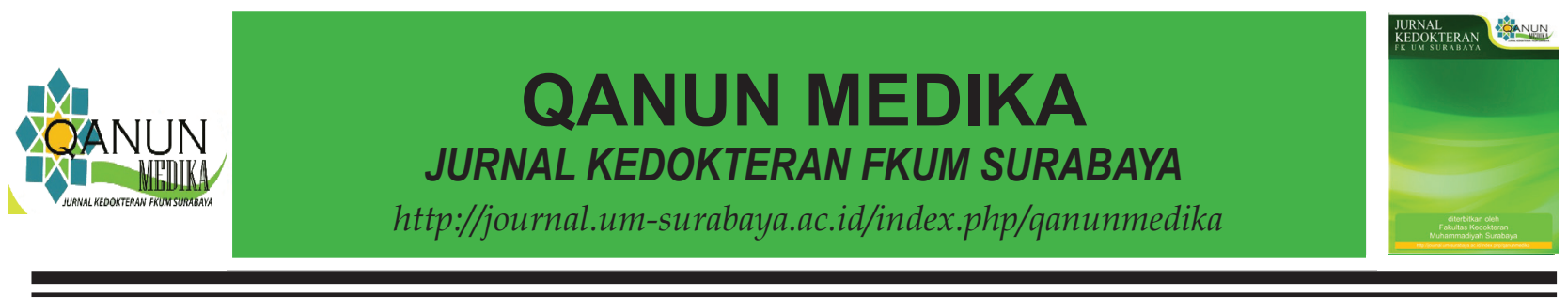

\section{INTRODUCTION}

A pandemic is an outbreak of infectious disease that infected many people in a large geographical area. Pandemic is global health emergencies at the highest level. According to WorldHealth Organization(WHO), an outbreak is defined as a pandemic if it meets three conditions: 1) the disease is a new emergence into a population, 2) the disease-causing agent infects humans and causes severe disease, and 3 ) the disease-causing agent spreads easily and continuously in humans. WHO has announced two pandemics, the Spanish Influenza in 1918s and H1N1 Influenza in the 2009s (Tamher \& Noorkasiani, 2008). On the $11^{\text {th }}$ of March 2020, WHO announced the third pandemic; it was the Corona Virus Disease 2019 (COVID-19). Since the WHO's declaration, this pandemic has attracted widespread attention, causing concern and panic among the world community (CDC, 2020).

The COVID-19 is a disease caused by Novel Coronavirus or SARS-Cov-2 Virus. As of May $10^{\text {th }} 2020$, there were 3.9 million confirmed cases globally, and the mortality reached 274 thousand, or the mortality rate was $6 \%$ (WHO, 2020). The National Health Commission of the Republic of China recorded at least 80 thousand confirmed COVID-19 cases, with the mortality reached 3 thousand. In America, the deaths due to COVID-19 reached a percentage of $8.2 \%$, higher than the epidemic threshold in various countries, which is $7.2 \%$ (PDPI, 2020). There were 14 thousand confirmed cases in Indonesia, and the mortality rate reached 991 people (7\%). The COVID-19 in Indonesia was first reported on the $2^{\text {nd }}$ of March 2020, and the number of confirmed cases has increased over time (Kemenkes RI, 2020).

The COVID-19 has a negative impact on the patients' quality of life because it might cause a dangerous acute attack (Li, Liu, Yu, Tang, \& Tang, 2020). The patients might get a fever, fatigue, myalgia, diarrhea, and shortness of breath. Those symptoms might be progressively worsened at a severe level. In the young age subjects or who do not have respiratory disease, shortness of breath can appear at any time or later. It has a terrible impact on the productive age group who will carry out the activities (Cascella, Rajnik, Cuomo, Dulebohn, \& Napoli, 2020). In severe cases, there can be rapid and progressive deterioration such as septic shock, metabolic acidosis that is difficult to correct, and dysfunction of the coagulation system within a few days. Although most patients have a good prognosis and only a small proportion might get into critical conditions even die, The COVID-19 is still a frightening issue (Wang et al., 2020).

Several regions, office affairs, or agencies have implemented their policies to anticipate the increasing number of sufferers and decrease transmission of COVID-19, including work from home (WFH). The WFH policy requires that all activities like studying, working, and even religious activity have to do at home. The Government of Indonesia in March 2020 decided to implement a Large-Scale Social Limitation (PSBB) in several cities and provinces in Indonesia. The COVID-19 pandemic and the ongoing restrictions might lead to arise in various psychosocial or mental health problems.

Previous studies have revealed psychosocial effects that affect mental health at the individual, community, and international levels during the pandemic quarantine. At the individual level, most people tend to fear falling ill or dying, feelings of helplessness, and stigma (Hall, Hall, \& Chapman, 2008). During the influenza epidemic, roughly $10 \%$ to $30 \%$ of the general public was worried about the possibility of infected by the virus (Rubin, Potts, \& Michie, 2010). The closure of public spaces and travel restrictions caused negative emotions at the individual level (Van Bortel et al., 2016). After 
the SARS outbreak, many studies investigated the psychological impact on uninfected communities. The study revealed significant levels of psychiatric morbidity found at a younger age and increased self-blame feelings (Sim, Huak Chan, Chong, Chua, \& Wen Soon, 2010). These conditions are in line with the theory that humans who are used to living in social groups will respond negatively when isolated. Those reactions are as a response to boredom, loneliness, confinement, and restriction (Sarner, 2020).

As one of the busiest cities in Bali Province, Denpasar City is implementing a PSBB similar system called Community Activity Restrictions (PKM) policy. At present, there is no data available that can describe events related to the psychosocial or mental health aspects of the Denpasar community during the COVID-19 pandemic. This study aimed to provide an overview of depression, anxiety, and stress in the Denpasar community during the COVID-19 pandemic. This research is expected to help the government and professional health services maintain the community's psychological wellbeing in dealing with COVID-19.

\section{METHODS}

This study was a descriptive observational study with a cross-sectional design. The sampling was carried out by a consecutive sampling method, which was conducted from April $20^{\text {th }}$ to April $27^{\text {th }} 2020$. The respondents living in Denpasar City and their age ranging from 18-65 years were included in this study. The evaluation of depression, stress, and stress levels used the Indonesian version of the Depression Anxiety and Stress Scale-21 (DASS-21) questionnaire. The data collection used Google forms that were distributed online to avoid direct contact with respondents during the COVID-19 pandemic. The respondents were instructed to give scores in each question ranging from 0 (never) to 3 (most often) based on their condition. The levels of depression, anxiety, and stress were classified based on the total score. The collected data then analyzed using SPSS v.23 software to determine the frequency and distribution of the data. This study has been approved by the Ethical Committee of Udayana University/ RSUP Sanglah Denpasar.

\section{RESULTS}

The characteristic of respondents of this study is presented in Table 1. The respondents were dominated by females, with a percentage of $56.9 \%$. The dominant respondents reside in South Denpasar with a frequency of more than one third and a percentage of $35 \%$. The majority of the respondents lived with their families or relatives, with a percentage of $85.6 \%$. The number of respondents whose ages were ranging from 18 to 25 years was more than half the total respondents, with a percentage of $63.7 \%$. The respondents' educational background was dominant of completed a diploma or bachelor degree with a frequency of more than half and a percentage of $55 \%$. The respondents who participated in this study were mostly unmarried, with a percentage of $66.3 \%$. The number of respondents living as students was dominated by more than one third and a percentage of $38.8 \%$. The respondents were also dominated by who rated no income category with a percentage of $44.4 \%$.

The data in table 2 showed that of 54 respondents who were married (married and divorced), the majority of them had 1-2 children with a percentage of $53.7 \%$. There were less than a quarter-respondents who had three or more children with a percentage of $22.2 \%$.

Based on the data in table 3 showed that of 93 people who worked, more than three-quarters did not get employment termination during the COVID-19 pandemic with a percentage of $83.9 \%$. There were two-thirds of respondents who had to get a decrease in income during the pandemic with a percentage of $67.0 \%$. 
Table 1. Characteristic of respondents

\begin{tabular}{|c|c|c|}
\hline Socio-demographics & Frequency & Percentage \\
\hline \multicolumn{3}{|l|}{ Sex } \\
\hline Male & 69 & 43.1 \\
\hline Female & 91 & 56.9 \\
\hline \multicolumn{3}{|l|}{ Domicile } \\
\hline North Denpasar & 31 & 19.4 \\
\hline East Denpasar & 41 & 25.6 \\
\hline South Denpasar & 56 & 35.0 \\
\hline West Denpasar & 32 & 20.0 \\
\hline \multicolumn{3}{|l|}{ Residence status } \\
\hline Alone & 23 & 14.4 \\
\hline With family or relatives & 137 & 85.6 \\
\hline \multicolumn{3}{|l|}{ Age } \\
\hline $18-25$ years & 102 & 63.7 \\
\hline $26-35$ years & 30 & 18.8 \\
\hline $36-45$ years & 15 & 9.4 \\
\hline $46-55$ years & 7 & 4.4 \\
\hline $56-65$ years & 6 & 3.8 \\
\hline \multicolumn{3}{|l|}{ Educational background } \\
\hline Elementary school & 1 & 0.6 \\
\hline Junior high school & 1 & 0.6 \\
\hline Senior high school & 70 & 43.8 \\
\hline Diploma or Bachelor degree & 88 & 55.0 \\
\hline \multicolumn{3}{|l|}{ Marital status } \\
\hline Married & 53 & 33.1 \\
\hline Unmarried & 106 & 66.3 \\
\hline Divorce & 1 & 0.6 \\
\hline \multicolumn{3}{|l|}{ Profession } \\
\hline Government employees & 17 & 18.1 \\
\hline Private employees & 45 & 7.5 \\
\hline Entrepreneur & 29 & 8.1 \\
\hline Retired & 3 & 1.9 \\
\hline Student & 62 & 38.8 \\
\hline Unemployment & 4 & 2.5 \\
\hline \multicolumn{3}{|l|}{ Monthly income } \\
\hline Below the UMK & 47 & 29.4 \\
\hline UMK or more & 42 & 26.3 \\
\hline No income & 71 & 44.4 \\
\hline Total & 160 & 100 \\
\hline
\end{tabular}




\section{QANUN MEDIKA}

JURNAL KEDOKTERAN FKUM SURABAYA

http://journal.um-surabaya.ac.id/index.php/qanunmedika

Table 2. Characteristic of the respondent's number of children

\begin{tabular}{lcc}
\hline \multicolumn{1}{c}{ Number of children } & Frequency & Percentage \\
\hline 1-2 children & 29 & 53.7 \\
3 or more children & 12 & 22.2 \\
Do not have children yet & 13 & 24.1 \\
\hline Total & 54 & 100 \\
\hline
\end{tabular}

Table 3. Characteristics of employment status during the COVID-19 pandemic

\begin{tabular}{lcc}
\hline Employment status & Frequency & Percentage \\
\hline $\begin{array}{l}\text { Termination of employment } \\
(\mathbf{n}=\mathbf{9 3})\end{array}$ & 15 & \\
Yes & 78 & 16.1 \\
No & & 83.9 \\
\hline A decrease in income & & \\
$(\mathbf{n}=\mathbf{1 0 0})$ & 67 & 67.0 \\
Yes & 33 & 33.0 \\
No & & \\
\hline
\end{tabular}

Table 4. Characteristic of respondents' psychosocial status

\begin{tabular}{lcc}
\hline \multicolumn{1}{c}{ Psychosocial status } & Frequency & Percentage \\
\hline Depression & 82 & 51.2 \\
Yes & 78 & 48.8 \\
No & & \\
\hline Anxiety & 85 & 53.1 \\
Yes & 75 & 46.9 \\
No & & \\
\hline Stress & 69 & 43.1 \\
Yes & 91 & 56.9 \\
No & 160 & 100 \\
\hline Total & & \\
\hline
\end{tabular}

The study shows that most respondents with a frequency of more than half experienced depression during the pandemic (51.2\%). In addition, more than half of the respondents also experienced anxiety (53.1\%), and more than half of respondents did not experience stress with a percentage of $56.9 \%$ (Table 4 ).
The data in table 5 showed that most respondents who got depression during the pandemic were classified as moderate degrees with a percentage of $31.7 \%$. Most of the respondents who experienced anxiety during the pandemic were classified as mild anxiety, with a $40.0 \%$ percentage. Most of the respondents who got stress during the pandemic were classified as moderate stress with a $42.0 \%$ percentage. 


\section{DISCUSSION}

Based on the study results, it was found that the majority of the respondents were depressed. This result is in line with a survey conducted by the Indonesian Association of Mental Medicine Specialists (PDSKJI), which found as many as $67 \%$ of 2.364 respondents spread in 34 provinces in Indonesia had psychological problems in the form of depression. These results were obtained after conducting an independent or self-examination via online about mental health-related impacts of the COVID-19 pandemic conducted on the official PDSKJI website. The main symptoms of depression felt by respondents were sleep disturbance, lack of confidence, fatigue without strength, and loss of interest (PDSKJI, 2020).

This study also found that the majority of the respondents experienced anxiety. This result is back in line with a survey conducted by PDSKJI, which found as many as $68 \%$ of the total respondents had psychological problems in the form of anxiety. These results were also obtained after conducting an independent or self-examination online about mental health-related impacts of the COVID-19 pandemic conducted on the official PDSKJI website. The most anxious symptoms felt by respondents are feeling something terrible will happen, worrying too much, irritability or annoyance, and it is hard to relax. The total number of respondents in that study were 2.364 respondents, dominated by female respondents $(72 \%)$ with a minimum age of 14 years and a maximum of 71 years (PDSKJI, 2020).

A survey conducted by PDSKJI found that $80 \%$ of respondents experienced psychological trauma related to COVID-19. As many as $80 \%$ of respondents have psychological stress symptoms due to experiencing or witnessing unpleasant events related to COVID-19.
After a prominent trauma, symptoms of stress are feeling distant and separated or disconnected from others, and continuously feeling alert, cautious, guarded. There are also other symptoms such as numbness, angry outbursts or irritability, sleeping difficulty, and concentration problems (PDSKJI, 2020). The results obtained by PDSKJI contradict the results obtained by researchers, which can be caused by sociodemographic differences, economic status, customs, culture, and other values.

The depression that arises during the COVID-19 pandemic can be attributed to one of Fraud's theories of psychosocial factors. Psychosocial factors that influence depression include stressful life events, which more often precede the first episode of mood disorders than later episodes. Fraud's theory also suggests that if a person is hit by stress before the first episode, it can cause long-lasting brain biology changes. These changes cause changes in various neurotransmitters and intraneuronal signaling systems, including the loss of several neurons and decreased synaptic contact. The impact is that an individual at high risk of experiencing repeated episodes of mood disorders, even without stressors from psychosocial. Psychosocial stressors, both acute, such as the loss of a loved one, or chronic stressors such as long-term financial shortages, interpersonal relationship difficulties, experiencing security threats, can cause depression during the pandemic (Kaplan \& Sadock, 2010).

The anxiety that arises during the COVID-19 pandemic can be attributed to Stuart's theories of behavioral factors. Based on this theory, anxiety arises because of specific environmental stimuli such as trapped situations, wrong thinking patterns, or circumstances that force unproductive behavior so that it can cause maladaptive reactions. Individuals in an unfamiliar situation or new environment are more easily experienced anxiety than in 
an environment where they usually occupy. Excessive assessment of the presence of danger in certain situations and underestimates the self's ability to overcome threats is a cause of anxiety in someone (Stuart, 2013).

Stress arising during the COVID-19 pandemic can be attributed to Nevid's theories of a complex process involving the autonomic nervous system and the endocrine system. Stress caused during the pandemic is not only psychological or emotional stress but also physical stress. Stress is received by the brain in response to be transmitted to the hypothalamuspituitary-adrenal (HPA) axis. The hypothalamus secretes corticotropic hormone (CRH), and $\mathrm{CRH}$ stimulates the pituitary gland to secrete adrenocorticotropic hormone (ACTH). ACTH will induce the adrenal cortex to release cortisol or corticosteroids as stress hormones. If the stressor continues to persist, and the individual experiences a failure to adapt, the individual enters the fatigue stage. The fatigue phase is characterized by the parasympathetic branch's dominance, resulting in a decreased heart rate and breathing speed. In addition to the stress that enters the fatigue stage, various complaints such as numbness, difficulty concentrating, and irritability appear (Nevid et al., 2005).

The COVID-19 pandemic period was not only a health problem but also involved the economic, political, social, and other sectors throughout the world. It is also related to making policy to cut the transmission of COVID-19. Strategies adopted in almost all countries must take into account public health analysis, such as restrictions on contact between people. This is the basis for a lockdown, quarantine, or independent isolation policy, not traveling outside the home or limiting other activities that risk increasing the opportunity for COVID-19 transmission (Xiang et al., 2020).

With the presence of this policy, the length of time staying at home certainly increases.
This can cause mental health disorders for some people related to changes in their daily lives' rhythm. There was a change in the frequency and quality of their socializing, which at first collectively became very limited and changed several other daily habits. If these changes cannot be adapted for a while, it is not impossible to cause severe mental health disorders such as stress, depression, irritability, difficulty sleeping, fear, confusion, boredom, anger, frustration, and even stigma (Brooks et al., 2020). A research in China, during the COVID-19 pandemic, $84.7 \%$ of respondents spent 20-24 hours a day at home. An evaluation of mental health complaints to respondents found that $16.5 \%$ of respondents experienced moderate-severe depression, $28.8 \%$ experienced moderate-severe anxiety, and $8.1 \%$ experienced moderate-severe stress. People who already have recurrent depressive disorder, these restrictions become one of the stressors that can trigger back the symptoms of depression they have (Wang et al., 2020).

The effects of economic losses are also one of the significant problems beyond the health problems arising from the COVID-19 pandemic. Job losses, financial depletion, and long-term impacts on the economy are also stressors for mental health disorders. In this condition, cortisol levels and activity in the amygdala increase, which can trigger mental health disorders such as depression, stress, and anxiety (Pfefferbaum \& North, 2020).

Psychosocial disorders such as depression, anxiety, and stress are known to reduce body immunity, while what is needed to ward off COVID-19 is good immunity. Various ways can be done to overcome the impact of social restrictions on mental health. To deal with depression can be done by spending time with loved ones, maintaining communications with family, friends, colleagues through social media or online, running a new routine, running a new hobby, and expressing negative thoughts 
or emotions regularly. To overcome anxiety can be done by recognizing fear or anxiety so that it can be appropriately managed, dividing precise time between leisure and work time, recognizing activities that give a feeling of calm and happiness, and still maintaining clarity of mind through meditation. Things that can be done to cope with stress are prioritizing physical and mental health over others, regular exercise and eating nutritious food, and meditation (Hiremath, Suhas Kowshik, Manjunath, \& Shettar, 2020).

\section{CONCLUSION}

In conclusion, dominant respondents were experienced psychosocial disorders during the COVID-19 pandemic in the form of depression $(51.2 \%)$ with a moderate degree $(31.7 \%)$, the anxiety $(53.1 \%)$ with a mild degree $(40.0 \%)$, and did not experience stress (53.1\%).

\section{REFERENCES}

Brooks, S. K., Webster, R. K., Smith, L. E., Woodland, L., Wessely, S., Greenberg, N., \& Rubin, G. J. (2020). The psychological impact of quarantine and how to reduce it: rapid review of the evidence. The Lancet, 395(10227), 912920. https://doi.org/10.1016/S01406736(20)30460-8

Cascella, M., Rajnik, M., Cuomo, A., Dulebohn, S. C., \& Napoli, R. (2020). Features, Evaluation and Treatment Coronavirus (COVID-19). Retrieved June 23, 2020, from Treasure Island (FL): StatPearls Publishing website: https://www.ncbi.nlm.nih.gov/books/ NBK554776/

CDC. (2020). How COVID-19 Spreads. Retrieved June 23, 2020, from Centers for Disease Control and Prevention website: https://www.cdc.gov/coronavirus/2019ncov/prevent-getting-sick/how-covid- spreads.html

Hall, R. C. W., Hall, R. C. W., \& Chapman, M. J. (2008). The 1995 Kikwit Ebola outbreak: lessons hospitals and physicians can apply to future viral epidemics. General Hospital Psychiatry, 30(5), 446-452. https://doi. org/10.1016/j.genhosppsych.2008.05.003

Hiremath, P., Suhas Kowshik, C. S., Manjunath, M., \& Shettar, M. (2020). COVID 19: Impact of lockdown on mental health and tips to overcome. Asian Journal of Psychiatry, 51(January), 102088. https:// doi.org/10.1016/j.ajp.2020.102088

Kaplan, H., \& Sadock. (2010). Sinopsis Psikiatri Ilmu Pengetahuan Prilaku Psikiatri Klinis (2nd ed.). Tangerang: Bina Rupa Aksara.

Kemenkes RI. (2020). Dashboard Data Kasus COVID-19 di Indonesia. Retrieved June 23, 2020, from Kementerian Kesehatan Republik Indonesia website: https://www. kemkes.go.id/article/view/20031900002/ Dashboard-Data-Kasus-COVID-19-diIndonesia.html

Li, H., Liu, S., Yu, X., Tang, S.-L., \& Tang, C. (2020). Coronavirus disease 2019 (COVID-19): current status and future perspectives. International Journal of Antimicrobial Agents, 55(5), 105951. https://doi.org/10.1016/j. ijantimicag.2020.105951

Nevid, J. S., Murad, J., Medya, R., Kristiaji, W. C., Greene, B., \& Rathus, S. A. (2005). Psikologi abnormal (5th ed.; R. Medya \& W. C. Kristiaji, Eds.). Jakarta: Erlangga.

PDPI. (2020). Pneumonia COVID-19 Diagnosis \& Penatalaksanaan di Indonesia. Retrieved from https://www.persi.or.id/ images/2020/data/buku_pneumonia_ covid19.pdf

PDSKJI. (2020). Swaperiksa Web PDSKJI Per Tanggal 14 Mei 2020. Retrieved June 23, 
2020, from Perhimpunan Dokter Spesialis Kedokteran Jiwa Indonesia website: http://pdskji.org/home

Pfefferbaum, B., \& North, C. S. (2020). Mental Health and the Covid-19 Pandemic. New England Journal of Medicine, 1-3. https:// doi.org/10.1056/NEJMp2008017

Rubin, G. J., Potts, H. W. W., \& Michie, S. (2010). The impact of communications about swine flu (influenza A HINIv) on public responses to the outbreak: Results from 36 national telephone surveys in the UK. Health Technology Assessment, 14(34), 183-266. https://doi.org/10.3310/ hta14340-03

Sarner, M. (2020). Maintaining mental health in the time of coronavirus. New Scientist, 246(3279), 40-46. https://doi. org/10.1016/S0262-4079(20)30819-8

Sim, K., Huak Chan, Y., Chong, P. N., Chua, H. C., \& Wen Soon, S. (2010). Psychosocial and coping responses within the community health care setting towards a national outbreak of an infectious disease. Journal of Psychosomatic Research, 68(2), 195-202. https://doi.org/10.1016/j. jpsychores.2009.04.004

Stuart, G. W. (2013). Buku Saku Keperawatan Jiwa (5th ed.). Jakarta: EGC.

Tamher, \& Noorkasiani. (2008). Flu burung : aspek klinis dan epidemiologis. Jakarta: Salemba Empat.
Van Bortel, T., Basnayake, A., Wurie, F., Jambai, M., Koroma, A. S., Muana, A. T., ... Nellums, L. B. (2016). Psychosocial effects of an Ebola outbreak at individual, community and international levels. Bulletin of the World Health Organization, 94(3), 210-214. https://doi.org/10.2471/ blt. 15.158543

Wang, C., Pan, R., Wan, X., Tan, Y., Xu, L., Ho, C. S., \& Ho, R. C. (2020). Immediate Psychological Responses and Associated Factors during the Initial Stage of the 2019 Coronavirus Disease (COVID-19) Epidemic among the General Population in China. International Journal of Environmental Research and Public Health, 17(5), 1729. https://doi. org/10.3390/ijerph17051729

WHO. (2020). Coronavirus disease (COVID-2019) situation reports. Retrieved June 23, 2020, from World Health Organization website: https:// www.who.int/emergencies/diseases/ novel-coronavirus-2019/situation-reports

Xiang, Y. T., Yang, Y., Li, W., Zhang, L., Zhang, Q., Cheung, T., \& Ng, C. H. (2020). Timely mental health care for the 2019 novel coronavirus outbreak is urgently needed. The Lancet Psychiatry, 7(3), 228-229. https://doi.org/10.1016/ S2215-0366(20)30046-8 